\title{
Correction to: Surgery for Gastric Remnant Cancer Results in Similar Overall Survival Rates Compared with Primary Gastric Cancer: A Propensity Score-Matched Analysis
}

\author{
Christian Galata, $\mathbf{M D}^{1}$, Ulrich Ronellenfitsch, $\mathbf{M D}^{2}$, Christel Weiß, $\mathbf{P h D}^{3}$, Susanne Blank, $\mathbf{M D}^{1}$, \\ Christoph Reißfelder, $\mathrm{MD}^{1}$, and Julia Hardt, $\mathrm{MD}^{1}$ \\ ${ }^{1}$ Department of Surgery, Universitätsmedizin Mannheim, Medical Faculty Mannheim, Heidelberg University, Mannheim, \\ Germany; ${ }^{2}$ Department of Visceral, Vascular and Endocrine Surgery, University Hospital Halle (Saale), Martin-Luther- \\ University Halle-Wittenberg, Halle (Saale), Germany; ${ }^{3}$ Department of Medical Statistics and Biomathematics, Medical \\ Faculty Mannheim, Heidelberg University, Mannheim, Germany
}

CORRECTION TO: ANN SURG ONCOL (2020) 27:4196-4203

HTTPS://DOI.ORG/10.1245/S10434-020-08669-2

The article Surgery for Gastric Remnant Cancer Results in Similar Overall Survival Rates Compared with Primary Gastric Cancer: A Propensity Score-Matched Analysis, written by Galata et al., was originally published electronically on the publisher's internet portal on June 2, 2020, without open access. With the authors' decision to opt for Open Choice the copyright of the article changed on September 29, 2021, to (C) The Author(s) and the article is forthwith distributed under a Creative Commons Attribution 4.0 International License.

Open Access funding enabled and organized by Projekt DEAL. The original article has been updated.

The original article can be found online at https://doi.org/10.1245/ s10434-020-08669-2.

(C) The Author(s) 2021

Published Online: 18 October 2021

J. Hardt, MD

e-mail: julia.hardt@umm.de
OPEN ACCESS This article is licensed under a Creative Commons Attribution 4.0 International License, which permits use, sharing, adaptation, distribution and reproduction in any medium or format, as long as you give appropriate credit to the original author(s) and the source, provide a link to the Creative Commons licence, and indicate if changes were made. The images or other third party material in this article areincluded in the article's Creative Commons licence, unless indicated otherwise in a credit line to the material. If material is not included in the article's Creative Commons licence and your intended use is not permitted by statutory regulation or exceeds the permitted use, you will need to obtain permission directly from the copyright holder. To view a copy of this licence, visit http://c reativecommons.org/licenses/by/4.0/.

Publisher's Note Springer Nature remains neutral with regard to jurisdictional claims in published maps and institutional affiliations. 